\title{
Neurologic, clinical, and immunologic features in a cohort of HTLV-1 carriers with high proviral loads
}

\author{
Sheila N. Ferraz ${ }^{1} \cdot$ Gabriela F. Costa $^{2}$ • José Abraão Carneiro Neto ${ }^{1} \cdot$ Thiago Hebert $^{2} \cdot$ Cassius J. V. de Oliveira $^{1}$. \\ Mariele Guerra $^{1}$ • Lívia M. A. Oliveira ${ }^{1}$ • Edgar M. Carvalho ${ }^{1,3,4}$ (D)
}

Received: 26 July 2019 / Revised: 23 March 2020 / Accepted: 23 April 2020 / Published online: 8 May 2020

(C) The Author(s) 2020

\begin{abstract}
A high proviral load (PVL) is recognized as a risk factor for human T cell leukemia virus-1-associated myelopathy/tropical spastic paraparesis (HAM/TSP), but there is a lack of prospective studies evaluating whether or not HTLV-1 carriers with high PVL are at risk of developing HAM/TSP or other HTLV-1-related diseases. Here, we compare the incidence of clinical manifestations and the cytokine levels in $30 \mathrm{HTLV}-1$ carriers with high (>50,000 copies $\left./ 10^{6} \mathrm{PBMC}\right)$ and an equal number of subjects with low proviral load. Participants were followed for 3 to 16 years (median of 11 years). The PVL, IFN- $\gamma$, TNF, and IL-10 levels were quantified at entry and at the end of the follow-up. Among the self-reported symptoms in the initial evaluation, only the presence of paresthesia on the hands was more frequent in the group with high PVL $(p<0.04)$. The production of IFN- $\gamma$ was higher in the group with high PVL group (median of 1308 versus $686 \mathrm{pg} / \mathrm{ml}, p<0.011$ ) when compared with the control group in the first assessment. There was no difference in the occurrence of urinary symptoms or erectile dysfunction, periodontal disease, Sicca syndrome, and neurologic signs between the two groups during the follow-up. The observation that none of the HTLV-1 carriers with high PVL and with exaggerated inflammatory response progressed to HAM/TSP indicates that other factors in addition to the PVL and an exaggerated immune response are involved in the pathogenesis of HAM/TSP.
\end{abstract}

Keywords HTLV-1-associated myelopathy $\cdot$ HTLV-1 $\cdot$ Proviral load $\cdot$ HTLV-1 carriers $\cdot$ Myelopathy

\section{Introduction}

The human T cell leukemia virus-1 (HTLV-1) was the first human retrovirus to be described (Poiesz et al. 1980) and is the etiologic agent of adult $\mathrm{T}$ cell leukemia/lymphoma (ATL) (Uchiyama et al. 1977) and HTLV-1-associated myelopathy or tropical spastic paraparesis (HAM/TSP) (Osame et al. 1986; Gessain et al. 1985). The HTLV-1 virus preferentially infects CD4 T cells but is also found in CD8 T cells, B cells, and dendritic cells (Bangham 2018; Martin et al. 2016). HTLV-1 infection activates genes that induce $\mathrm{T}$ cell proliferation and

Edgar M. Carvalho

imuno@ufba.br

1 Immunology Service, Professor Edgard Santos University Hospital, Federal University of Bahia, Salvador, Brazil

2 Escola Bahiana de Medicina e Saúde Pública, Salvador, Bahia, Brazil

3 Instituto Gonçalo Moniz (FIOCRUZ-BA), Fundação Oswaldo Cruz, Rua Waldemar Falcão, 121, Candeal, Salvador, Bahia, Brazil

4 National Institute of Science and Technology in Tropical Diseases (INCT-DT), CNPq, Salvador, Brazil activation with an exaggerated production of proinflammatory cytokines such as TNF, IL-1, IFN- $\gamma$, TGF- $\beta$, CXCL-9, and CXCL-10 (Ando et al. 2013; Futsch et al. 2017; Sato et al. 2013). The high proviral load usually above 50,000 copies per $10^{6}$ cells and the exacerbated inflammatory response are considered the main biomarkers of HAM/TSP (Grassi et al. 2011; Olindo et al. 2006; Santos et al. 2012). HAM/TSP is characterized by a slowly progressive spastic paraparesis, neurogenic bladder, and less visible sensory signals (Araújo et al. 2009). About $20 \%$ of individuals infected with HTLV-1 without HAM/TSP have urinary dysfunctions, especially due to overactive bladder (Troisgros et al. 2017). Erectile dysfunction is also observed in more than $40 \%$ of virus-infected subjects (de Oliveira et al. 2017). In addition to the aforementioned diseases, individuals infected with HTLV-1 have more chronic periodontitis, Sicca syndrome, and arthropathy than seronegative individuals (Motokawa et al. 1996; Poetker et al. 2011; Caskey et al. 2008).

Previous studies with HTLV-1-infected subjects who did not fulfill the criteria for HAM/TSP have shown a greater occurrence of neurologic symptoms, such as weakness in the lower limbs, hyperreflexia, and altered vibratory sensitivity, as 
well as urinary dysfunction and erectile dysfunction, than in seronegative controls (Biswas et al. 2009; Caskey et al. 2008). It has also been observed that many HTLV-1-infected individuals who do not meet the criteria for HAM/TSP present neurological complaints related to sensorial, motor, urinary, or autonomic manifestations (Tanajura et al. 2015). Usually in virus-infected individuals who exhibit these symptoms or diseases, the PVL is high or virus proteins are documented in the compromised tissue, supporting the important role of PVL in the passage of viruses to the tissues as a risk factor for carriers' progress to disease. However, a significant proportion of HTLV-1 carriers have PVL as high as patients with HAM/ TSP (Santos et al. 2006; Martins et al. 2017). The majority of the studies correlating viral load and immunologic responses with clinical manifestations in HTLV-1 are cross-sectional. There is a lack of prospective studies evaluating if subjects with high viral burdens for long periods of time will develop HTLV-1-associated diseases as well as immunological abnormalities similar to those observed in patients with HAM/TSP.

\section{Methods}

\section{Type of study and participants}

This is a prospective cohort study with the participation of HTLV-1-infected subjects admitted between 2001 and 2016 in the Multidisciplinary HTLV-1 Clinic of the University Hospital Professor Edgard Santos, Salvador, Bahia, Brazil. The study subjects were classified as exposed (high PVL) or non-exposed (low PVL). The exposed group had PVL greater than 50,000 copies/10 ${ }^{6}$ PBMC (Grassi et al. 2011) without any evidence of probable or definitive myelopathy (De Castro-costa et al. 2006). Non-exposed subjects were defined as HTLV-1 carriers with PVL lower than 50,000 copies/ $10^{6}$ cells at admission.

The HTLV-1 infection was diagnosed by the enzymelinked immunosorbent assay (ELISA) - (Cambridge Biotech Corp., Worcester, MA, USA) and confirmed by Western blot test, HTLV blot (Genelabs, Singapore). Initially, 92 HTLV-1 carriers were identified, and 31 had high PVL. As one of these patients had neurosyphilis, he was excluded. Thus, 30 subjects with a high PVL and 30 with a low PVL matched for age $( \pm$ 5 years) and gender participated in the study. None of the subjects was taking immunosuppressive drugs or was using phosphodiesterase inhibitors.

\section{Study design}

The subjects answered a standard questionnaire and had a clinical and neurological physical examination performed once a year. Information about how they were referred to the clinic, previous history of blood transfusions, breast feeding, and sexual behavior were recorded. Patients were evaluated by neurologists, urologists, rheumatologists, dentists, and psychologists. The outcomes determined were Sicca syndrome, periodontitis, urinary dysfunction, erectile dysfunction, walking difficulty, running difficulty, hyperreflexia (grade 3 or 4), and Babinski reflexes. Sicca syndrome was defined by xerophthalmia, and evidence of dry mouth and chronic periodontal diseases by the criteria was established by the International Association of Periodontal Disease. Low urinary tract symptoms such as nocturia, frequency, urgency, and incontinence were recorded, as well as void dysfunction. The erectile dysfunction was determined by the international index of erectile function (IIEF-5).

\section{Cell separation, cell culture, and determination of cytokine}

Peripheral blood mononuclear cells (PBMCs) were isolated from heparinized blood samples by density gradient centrifugation with Ficoll-Hypaque (GE Healthcare Bio-Sciences, Uppsala, Sweden). The cells were cultured in RPMI 1640 (Life Technologies Gibco BRL, Grand Island, NY), 10\% human AB serum (Sigma, St. Louis, MO, USA), glutamine, HEPES, and antibiotics (complete RPMI). Cytokines were determined in supernatants of unstimulated PBMC cultures as previously described (Santos et al. 2012). Briefly, after mononuclear cell separation, the cells were washed twice in saline and were adjusted to the concentration of $3 \times 10^{6}$ cells/ $\mathrm{ml}$ in RPMI 1640 (Life Technologies Gibco BRL, Gran Island, NY, USA) supplemented with $10 \%$ of fetal bovine serum (Sigma, St Louis, MO, USA), glutamine, HEPES, and antibiotics. Unstimulated cells, $3 \times 10^{6}$ cells $/ \mathrm{ml}$, were incubated for $72 \mathrm{~h}$ at $37^{\circ} \mathrm{C} 5 \% \mathrm{CO}_{2}$, and the supernatants were harvested. Cytokines were determined in supernatants of unstimulated PBMC cultures by sandwich ELISA using reagents from BD Biosciences Pharmingen, San Jose, CA, USA, and the results are expressed in $\mathrm{pg} / \mathrm{ml}$.

\section{Determination of the Proviral load}

The DNA was extracted from $10^{6}$ PBMCs using proteinase $\mathrm{K}$ and salting-out method. The HTLV-1 proviral load was quantified using a real-time Taq-Man PCR method as previously described using the ABI Prism 7700 Sequence detector system (Applied Biosystems) (Dehée et al. 2002). Albumin DNA was used as an endogenous reference. The normalized value of the HTLV-1 proviral load was calculated as the ratio of HTLV-1 DNA average copy number/albumin DNA average copy number $\times 2 \times 10^{6}$ and expressed as the number of HTLV-1 copies per $10^{6}$ PBMCs. 


\section{Statistical analysis}

All the data were kept in an electronic data bank, the Research Electronic Data Capture (Harris et al. 2009). Data was expressed as median and interquartile (IQ) range in all figures. Categorical variables were analyzed using the Pearson's Chisquared test or Fisher exact test. The proviral load and cytokine levels were expressed in median, and the comparison was performed by the Mann-Whitney $U$ test. For the paired samples, we used the McNemar test. The logistic regression analysis was used to identify independent variables associated with the existence of mono/oligosymptomatic subjects. We also determined the intraindividual PVL and cytokine changes by the coefficient of variation (Martins et al. 2017). Correlations between two variables were examined by Spearman rank correlation analysis. All statistical analysis was performed using SPSS version 17 and were considered significant when $p<0.05$.

\section{Results}

A total of 60 individuals infected by HTLV-1 were eligible for this study and included in the analysis. The demographic, epidemiological, and clinical features of the participants are shown in Table 1. There was a predominance of female individuals $(66.7 \%)$. These subjects were mainly referred by blood banks, being $60 \%$ of the total in the group of subjects with high proviral load and $80 \%$ in subjects with low proviral load. The mean age was slightly higher in the group of nonexposed subjects, 56.2 years versus 55.5 years $(p=0.81)$. In the group of carriers with high PVL, the HTLV-1 carriers were followed a median of 11 years versus 11.5 years in the nonexposed group $(p=0.57)$.

The comparative analysis of HTLV-1 carriers at study entry and in the last evaluation is shown in Table 2. No significant differences were identified between the neurological signs and symptoms at the final follow-up in the exposed group indicating that carriers with high proviral load were not more likely than controls to report complaints about the ability to run and to walk with urinary tract symptoms and paresthesia in the feet. There was also no difference in the frequency of joint pain and periodontal disease during the follow-up. The cases had more xerostomia at the last evaluation compared with the entry. Moreover, in a logistic regression analysis, there was no association between PVL and cytokine level with mono/ oligosymptomatic subjects (data not shown). In summary none of the HTLV-1 carriers during the follow-up developed probable HAM or definitive HAM/TSP. The evaluation of the decrease in PVL between the two groups at the entry and during the follow-up is shown in Fig. 1. While there was a decrease in the high PVL among carriers during the follow-up, there was no significant change in PVL among the controls. However, when the coefficient of variation was evaluated, there was no difference in the PVL during the follow-up.

The cytokine production at baseline and in the last evaluation is shown on Fig. 2. The concentration of IFN- $\gamma$ in supernatants of PBMC was higher in the group with a high proviral

Table 1 Demographic, epidemiologic characteristics, and clinical aspects of HTLV-1 carriers, classified according to the proviral load at study entry

\begin{tabular}{|c|c|c|c|}
\hline Characteristic & High proviral load carriers ( $n$ 30) & Low proviral load carriers $(n 30)$ & $p$ value \\
\hline Female sex & $20(66.7 \%)$ & $20(66.7 \%)$ & \\
\hline Median age. y & $55.5( \pm 11.6)$ & $56.2( \pm 11.2)$ & $=0.81^{\mathrm{c}}$ \\
\hline Patient Referral & & & $=0.19^{\mathrm{a}}$ \\
\hline Blood banks & $18(60 \%)$ & $24(80 \%)$ & \\
\hline Other clinics & $1(3.3 \%)$ & 0 & \\
\hline Relatives & $1(3.3 \%)$ & $2(6.7 \%)$ & \\
\hline Others & $10(33.3 \%)$ & $4(13.3 \%)$ & \\
\hline Blood transfusion & $4(13.8 \%)$ & $1(3.3 \%)$ & $=0.19^{\mathrm{b}}$ \\
\hline Years of follow-up (median [interquartile range]) & $11(8.5-13)$ & $11.5(8-12)$ & $=0.57^{\mathrm{c}}$ \\
\hline \multicolumn{4}{|l|}{ Comorbidities } \\
\hline Diabetes mellitus & $4(13.3 \%)$ & $3(10 \%)$ & $>0.99^{\mathrm{b}}$ \\
\hline Hypothyroidism & $3(10 \%)$ & $1(3.3 \%)$ & $=0.61^{\mathrm{b}}$ \\
\hline Osteoarthritis & $7(23.3 \%)$ & $13(43.3 \%)$ & $=0.10^{\mathrm{a}}$ \\
\hline HBV infection & 0 & $1(3.3 \%)$ & $>0.99^{\mathrm{b}}$ \\
\hline HCV infection & 0 & $1(3.3 \%)$ & $>0.99^{b}$ \\
\hline
\end{tabular}

*Chi-square or Fisher's exact test was used if characteristic was categorical and Mann-Whitney $U$ test if continuous

a $\chi 2$ test; b Fisher's exact test; c Mann-Whitney $U$ test

HTLV-1, human T-cell leukemia virus-1; HBV, hepatitis B virus; HCV, hepatitis C virus 
Table 2 Clinical symptoms and signs in HTLV-1-infected subjects with high or low proviral load at admission and in the last evaluation

\begin{tabular}{|c|c|c|c|c|c|c|c|c|}
\hline \multirow[t]{2}{*}{ Clinical features } & \multicolumn{3}{|c|}{ Low proviral load carriers } & \multicolumn{3}{|c|}{ High proviral load carriers } & \multicolumn{2}{|c|}{ Comparison between groups } \\
\hline & Admission & $\begin{array}{l}\text { Final } \\
\text { evaluation }\end{array}$ & $\begin{array}{l}p \\
\text { value }^{\mathrm{a}}\end{array}$ & Admission & $\begin{array}{l}\text { Final } \\
\text { evaluation }\end{array}$ & $\begin{array}{l}p \\
\text { value }^{\mathrm{a}}\end{array}$ & $\begin{array}{l}\text { Admission } p \\
\text { value }\end{array}$ & $\begin{array}{l}\text { Final evaluation } p \\
\text { value }\end{array}$ \\
\hline Urological symptoms & $4(13.3 \%)$ & $4(13.3 \%)$ & $>0.99$ & $5(16.7 \%)$ & $5(16.7 \%)$ & 1 & $>0.99^{\mathrm{b}}$ & $0.99^{\mathrm{b}}$ \\
\hline Effort urinating & $3(10 \%)$ & 0 & 0.25 & $1(3.3 \%)$ & $2(6.7 \%)$ & $>0.99$ & $0.61^{\mathrm{b}}$ & $0.49^{\mathrm{b}}$ \\
\hline Urgency & $1(3.3 \%)$ & 0 & $>0.99$ & 0 & 0 & - & $>0.99^{\mathrm{b}}$ & - \\
\hline $\begin{array}{l}\text { Stress urinary } \\
\text { incontinence }\end{array}$ & 0 & 0 & - & $3(10 \%)$ & $1(3.3 \%)$ & 0.63 & $0.24^{\mathrm{b}}$ & $>0.99^{\mathrm{b}}$ \\
\hline Erectile dysfunction & 0 & $3 / 10(30 \%)$ & 0.25 & 0 & 0 & - & - & $0.21^{\mathrm{b}}$ \\
\hline Others & 0 & $1(3.3 \%)$ & $>0.99$ & $1(3.3 \%)$ & $2(6.7 \%)$ & $>0.99$ & $>0.99^{\mathrm{b}}$ & $>0.99^{\mathrm{b}}$ \\
\hline \multicolumn{9}{|l|}{ Neurological symptoms } \\
\hline Difficulty running & $2(6.7 \%)$ & $6(20 \%)$ & 0.22 & $3(10 \%)$ & $5(16.7 \%)$ & 0.69 & $>0.99^{\mathrm{b}}$ & $0.74^{\mathrm{c}}$ \\
\hline Difficulty walking & 0 & $3(10 \%)$ & 0.25 & $1(3.3 \%)$ & $2(6.7 \%)$ & $>0.99$ & $>0.99^{\mathrm{b}}$ & $>0.99^{\mathrm{b}}$ \\
\hline Hand numbness & $2(6.7 \%)$ & $4(13.3 \%)$ & 0.68 & $8(26.7 \%)$ & $5(16.7 \%)$ & 0.51 & $0.04^{\mathrm{c}}$ & $>0.99^{\mathrm{b}}$ \\
\hline Foot numbness & $2(6.7 \%)$ & $4(13.3 \%)$ & 0.68 & $7(23.3 \%)$ & $6(20 \%)$ & $>0.99$ & $0.14^{\mathrm{b}}$ & $0.49^{\mathrm{c}}$ \\
\hline Biceps hyperreflexia & $4(13.3 \%)$ & $2(6.7 \%)$ & 0.5 & $1(3.3 \%)$ & $1(3.3 \%)$ & 1 & $0.35^{\mathrm{c}}$ & $>0.99^{\mathrm{b}}$ \\
\hline Patellar hyperreflexia & $4(13.3 \%)$ & $5(16.7 \%)$ & $>0.99$ & $5(16.7 \%)$ & $7(23.3 \%)$ & 0.62 & $>0.99^{\mathrm{b}}$ & $0.52^{\mathrm{c}}$ \\
\hline Babinski sign & 0 & 0 & & 0 & 0 & & & \\
\hline \multicolumn{9}{|c|}{ Rheumatological symptoms } \\
\hline \multicolumn{9}{|l|}{ Joint pain } \\
\hline Monoarticular & $1 / 28(3.6 \%)$ & $4(13.3 \%)$ & 0.5 & $2(6.7 \%)$ & $5(16.7 \%)$ & 0.37 & $>0.99^{\mathrm{b}}$ & $>0.99^{\mathrm{b}}$ \\
\hline Oligoarticular & $1 / 28(3.6 \%)$ & $3(10 \%)$ & 0.62 & $1(3.3 \%)$ & $7(23.3 \%)$ & 0.07 & $>0.99^{\mathrm{b}}$ & $0.16^{\mathrm{c}}$ \\
\hline Polyarticular & $0 / 28$ & $2(6.7 \%)$ & 0.5 & 0 & $1(3.3 \%)$ & $>0.99$ & - & $>0.99^{\mathrm{b}}$ \\
\hline Xerostomia & $4(13.3 \%)$ & $6 / 23(26.1 \%)$ & 0.68 & $3(10 \%)$ & $9 / 25(36 \%)$ & 0.03 & $>0.99^{\mathrm{b}}$ & $0.46^{\mathrm{c}}$ \\
\hline Xerophthalmia & $\begin{array}{l}6 / 29 \\
\quad(20.7 \%)\end{array}$ & $6(20 \%)$ & $>0.99$ & $5(16.7 \%)$ & $13(43.3 \%)$ & 0.06 & $0.69^{\mathrm{c}}$ & $0.052^{\mathrm{c}}$ \\
\hline Periodontal disease & $\begin{array}{l}6 / 16 \\
(37.5 \%)\end{array}$ & $12 / 21(57.1 \%)$ & $>0.99$ & $\begin{array}{l}11 / 24 \\
(45.8 \%)\end{array}$ & $12 / 24(50 \%)$ & $>0.99$ & $0.60^{\mathrm{c}}$ & $0.63^{\mathrm{c}}$ \\
\hline
\end{tabular}

*Chi-square or Fisher's exact test was used if characteristic was categorical and McNemar test for paired data a McNemar test; B Fisher's exact test; c $\chi^{2}$ Test

Fig. 1 Comparative analysis between the baseline proviral load and the last evaluation in HTLV-1 carriers with high and low proviral load. Data represents the proviral load expressed as number of HTLV-1 copies per $10^{6}$ peripheral blood mononuclear cells. Wilcoxon signed-rank test was used for the statistical analysis. $p$ value $<0.05$ was considered significant
High Proviral Load Carriers

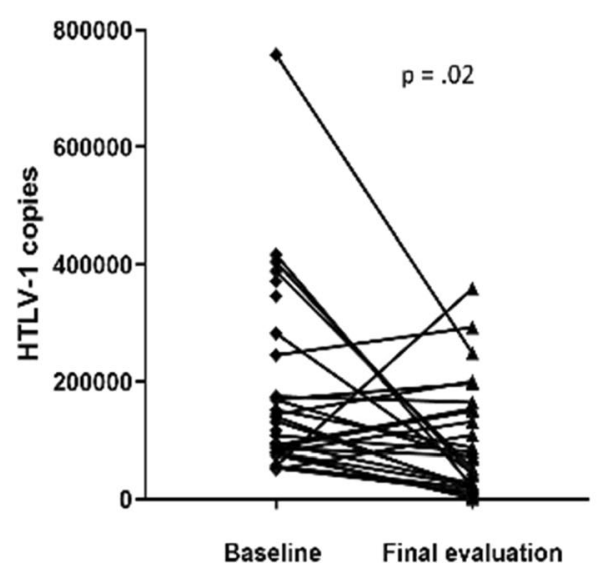

Low Proviral Load Carriers

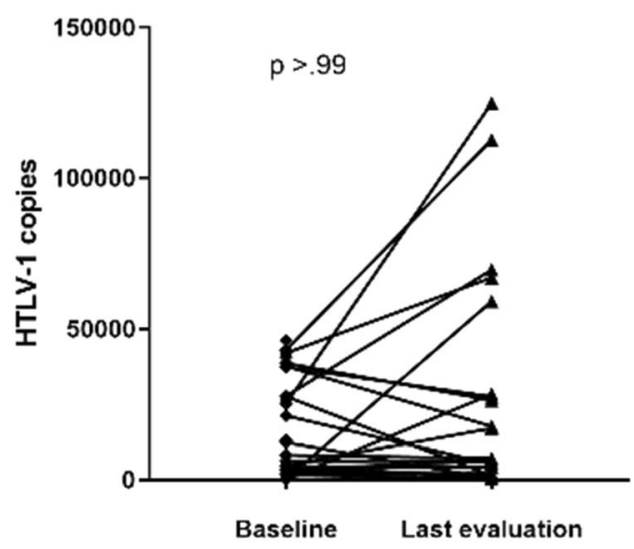


Fig. 2 Cytokine concentrations in supernatants of unstimulated mononuclear cell cultures of HTLV-1 carriers with high and low proviral load at study entry and at the last evaluation: a IFN$\gamma, \mathbf{b}$ TNF, c IL10. Cytokine levels were measured by ELISA in supernatant of unstimulated $3 \times 10^{6}$ peripheral blood mononuclear cells after $72 \mathrm{~h}$ of incubation. Wilcoxon signed-rank test was used for the statistical analysis. $p$ value $<0.05$ was considered significant
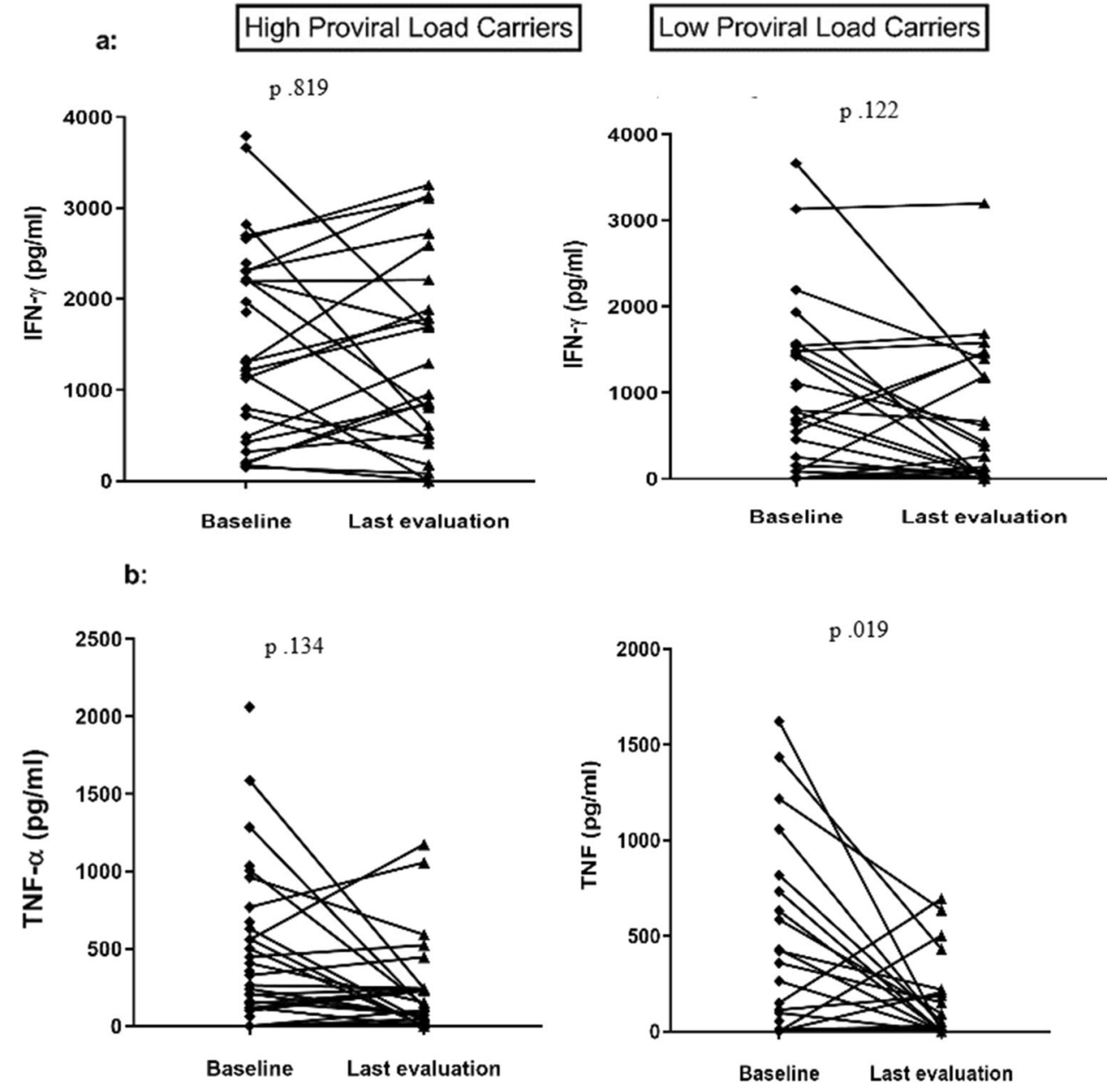

c:

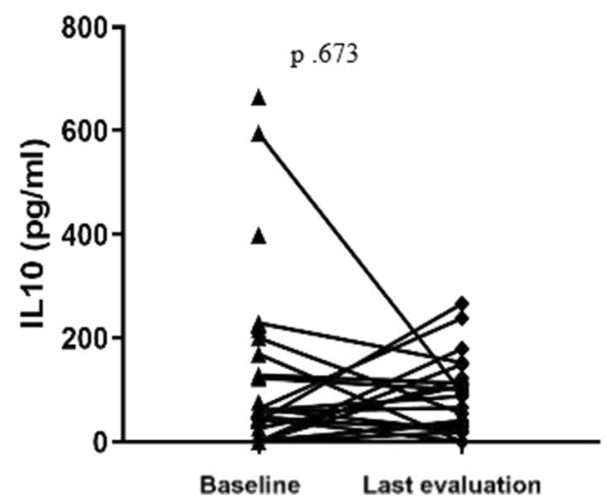

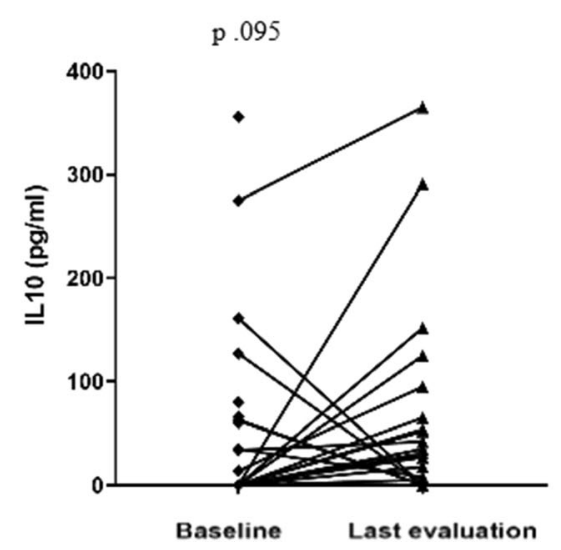

load (median of 1308 versus $686 \mathrm{pg} / \mathrm{ml}, p=0.011$ ) when compared with the control group in the first evaluation, as well as the concentration of IL-10 (median of $53 \mathrm{pg} / \mathrm{ml}$ versus $0 \mathrm{pg} /$ $\mathrm{ml}, p=0.01)$. There were no differences in the levels of TNF and IL-10 at baseline, and in the last evaluation, there was a decrease in TNF concentration in both groups, with a significant difference in the group with low proviral load with median of $105 \mathrm{pg} / \mathrm{ml}$ at admission versus $22 \mathrm{pg} / \mathrm{ml}$ in the last evaluation, $p=0.01$ ).

The correlations between the production of cytokines in supernatants of PBMC as well as between cytokines and PVL are shown in Table 3. There was a direct correlation between IFN- $\gamma$ levels and PVL in low PVL carriers in the first $(r=0.55)$ and in the last $(r=0.65)$ evaluation and between 
Table 3 Correlations between serum cytokines and proviral load from HTLV-1 carriers at study entry and at the last evaluation

\begin{tabular}{lllll}
\hline Correlations & \multicolumn{2}{l}{ High proviral load carriers } & & \multicolumn{2}{l}{ Low proviral load carriers } \\
\cline { 2 - 4 } & Study entry & Last evaluation & Study entry & $0.55(<0.01)$ \\
\hline IFN- $\gamma$ x PVL & $-0.013(=0.95)$ & $-0.23(=0.29)$ & $0.29(=0.12)$ & $0.65(<0.001)$ \\
TNF x PVL & $0.117(=0.54)$ & $0.002(=0.99)$ & $0.30(=0.11)$ & $0.43(=0.03)$ \\
IL10 x PVL & $0.15(=0.41)$ & $0.27(=0.24)$ & $0.54(<0.001)$ & $0.20(=0.37)$ \\
IFN- $\gamma$ x TNF & $0.45(=0.01)$ & $0.72(<0.001)$ & $0.45(=0.01)$ & $0.31(=0.14)$ \\
IFN- $\gamma$ x IL10 & $0.30(=0.10)$ & $0.76(<0.001)$ & $0.35(=0.06)$ & $0.45(=0.03)$ \\
TNF x IL10 & $0.48(<0.01)$ & $0.45(=0.03)$ & \\
\hline
\end{tabular}

Spearman correlations were calculated between parameters. The " $\mathrm{r}$ " indexes are shown, as well the ( $p$ value)

PVL, proviral load

TNF and PVL in the same group in the last evaluation $(r=$ $0.43)$. Regarding the correlation between proinflammatory versus anti-inflammatory cytokines, it is important that the only strong correlation observed was a direct correlation between IFN- $\gamma$ and IL-10 in the high PVL $(r=0.76)$ in the last evaluation. There was a direct correlation between TNF and IL-10 in all evaluations except in the first evaluation of the group with low PVL. Regarding the proinflammatory cytokines, there was a direct correlation between IFN- $\gamma$ and TNF in all evaluations in both groups.

\section{Discussion}

The HAM/TSP only occurs in less than 5\% of HTLV-1infected subjects (Gessain and Mahieux 2012), but there are other clinical manifestations associated with this virus such as ATL (Poiesz et al. 1980), Sicca syndrome (Lima et al. 2016), periodontal disease (Garlet et al. 2010), and arthropathy (Frenzel et al. 2014). Moreover, 40\% of the HTLV-1infected subjects without HAM/TSP have neurologic symptoms and signs related to spinal cord involvement, such as paresthesia, weakness in the inferior limbs, difficult walking, urologic manifestations of neurogenic bladder, and erectile dysfunction (Tanajura et al. 2015; Biswas et al. 2009; Poetker et al. 2011; Caskey et al. 2008). The HTLV-1 PVL has been considered the most important biomarker of HAM/ TSP, and patients with HAM/TSP have higher production of proinflammatory cytokines than HTLV-1 carriers (Domingos et al. 2017; Guerreiro et al. 2006; Santos et al. 2012). It is known that HTLV-1 carriers may present PVL and proinflammatory cytokine levels as high as what is observed in HAM/ TSP (Santos et al. 2004). However, there is a lack of longitudinal studies evaluating if overtime carriers with high HTLV-1 PVL will develop more clinical and neurogenic diseases than carriers with low proviral load or if they are at a high risk to develop HAM/TSP. In the present study, we showed in a cohort study that HTLV-1 carriers who have a high viral burden and also produce high levels of proinflammatory cytokines may not develop more clinical and neurological signs and symptoms than HTLV-1 carriers with low PVL.

The two groups of HLV-1 carriers of the present study had similar demographic and epidemiologic profiles at admission, but they differ regarding the proviral load and the production of proinflammatory cytokines. Additionally, carriers from both groups had no difference in the clinical or neurological examination at admission. The only exception was the presence of paresthesia on the hands, which was more frequent in the group with a high PVL. It is relevant that two previous studies aimed to identify clinical and neurological manifestations related to HTLV-1 found higher frequencies of Sicca syndrome, periodontal disease, urinary complaints of neurogenic bladder, hyperreflexia, and even difficulty walking in HTLV-1 carriers than in the no infected subjects (Caskey et al. 2008; Poetker et al. 2011). The higher frequency of clinical and neurological manifestations in carriers in these previous studies compared with our data may be explained by the improvement in knowledge about the clinical spectrum of HTLV-1 infection in the last 10 years, mainly due to the understanding that urinary dysfunction was one of the manifestation associated to HTLV-1 infection. In the present study, HTLV-1 carriers were defined as patients who did not have HAM/TSP or probable HAM/TSP, that is, a form of HTLV-1 infection characterized mainly by urinary dysfunction (De Castro-costa et al. 2006; Tanajura et al. 2015).

The enhanced $T$ cell activation contributes to the passage of cells through the brain-blood barrier and persistent secretion of proinflammatory cytokines (Bangham 2018). A previous study showed that a proviral load higher than 50,000 copies for $10^{6} /$ lymphocytes is a good predictor for the diagnosis of HAM/TSP (Grassi et al. 2011). It is known that HAM/TSP is a late manifestation of HTLV-1 infection occurring usually after the fourth decade of life. However, children who had a previous history of infective dermatitis develop HAM/TSP during adolescence or as young adults (de Oliveira et al. 2005). These children with infective dermatitis without evidence of HAM/ 
TSP present PLV and proinflammatory cytokines as high as patients with HAM/TSP supporting the important role of high HTLV-1 proviral load in early progression of HTLV-1 carriers to HAM/TSP (Nascimento et al. 2009). However, in the present study, HTLV-1 carriers with high PVL, followed for long periods of time, did not develop more clinical or neurological disease than HTLV-1 carriers with low PVL. Variability in the PVL has been observed in other studies during the follow-up of HTLV-1-infected subjects (Demontis et al. 2013; Matsuzaki et al. 2001). However, it cannot be ruled out that in these carriers, host defense mechanisms developed during the course of the viral infection contributed to the decrease in the proviral load and the maintenance of a carrier state.

Previous studies have shown that proinflammatory cytokine levels in serum and supernatants of PBMC are higher in patients with HAM/TSP than in HTLV-1 carriers (Grassi et al. 2011; Matsuzaki et al. 2001; Nagai et al. 1998; Olindo et al. 2005). The proinflammatory cytokines such as IL-1 $\beta$, IL-6, TNF, CXCL9, CXCL10, and IFN- $\gamma$ participate in the pathology of several chronic inflammatory diseases including rheumatoid arthritis (Pandya et al. 2017), coronary diseases (Hansson 2005), cerebral malaria (Rudin et al. 1997), tegumentary leishmaniasis (Oliveira et al. 2014), and Chagas diseases (Gomes et al. 2003; Poveda et al. 2014). We have previously shown that patients with HAM/TSP display a decreased ability to down-modulate T cell response (Santos et al. 2006) in comparison with HTLV-1 carriers and that CD8 T cells are the main source of IFN- $\gamma$ and TNF among T cells in HAM/TSP (Santos et al. 2004). We do not know the mechanism through which HTLV-1 infection induces central nervous system damage, but there is much evidence of the participation of proinflammatory cytokines, as well as CD8 T cell activation in the pathology of infectious diseases. Although baseline production of IFN- $\gamma$ was higher in cases with high proviral loads than in control groups, both groups produced high amounts of IFN- $\gamma$ and TNF, indicating that a high production of proinflammatory cytokines may occur even in the absence of neurological disease.

A correlation between proinflammatory and antiinflammatory cytokines has been observed in subjects with HTLV infection, and there is a direct correlation between IFN- $\gamma$ and IL-10 as well in TNF and IL-10 in HTLV-1 carriers (Carvalho et al. 2001). In the present study, we evaluated if there was a correlation between the cytokines in carriers with high and low PVL. Interestingly, there was no correlation between IFN- $\gamma$ and IL-10 in the group with high PVL at entry, but there was a strong direct correlation among these cytokines in the last evaluation. It is possible that the correlation between the anti-inflammatory cytokine IL-10 with the proinflammatory cytokine IFN- $\gamma$ during the follow-up contributes to prevent the damage caused by exacerbated inflammatory response observed in HTLV1 infection.
The increase in the frequency of cells expressing TNF is associated with pathology in HTLV-1 infection (Santos et al. 2004; Nakamura et al. 1993; Neco et al. 2017). Moreover, while the frequency of cells expressing TNF and the intensity of expression of TNF was similar in CD4+ T cells from HTLV-1 carriers and patients with HAM/TSP, there was higher frequency of CD8+ T cells expression TNF in HAM/ TSP than in HTLV-1 carriers suggesting the participation of TNF in the pathogenesis of HAM/TSP. The decrease in TNF observed in patients during the follow-up may help to avoid tissue damage and may be a marker of protection against HAM/TSP.

An analysis of the correlation between PVL and cytokines in the two groups studied showed different profiles. While low PVL carriers showed a direct correlation between IFN- $\gamma$ and TNF production and PVL in the last evaluation, in the group of subjects with a high PVL, this correlation was not observed. The existence of a correlation between proviral load and cytokine production was observed in other studies (Lima et al. 2016; Starling et al. 2013). However, the enhancement in the production of proinflammatory cytokines may be due to other factors as the nature of $\mathrm{T}$ cell activation and production of other cytokines. This may explain the absence of correlation between PVL and proinflammatory cytokines in the high PVL group.

We recognized that this study has some limitations including the identification of other factors associated with decreased susceptibility to the development of HAM/TSP, the limited follow-up of the carriers, and the lack of evaluation TAX-specific $\mathrm{CD} 8^{+} \mathrm{T}$ cells. The presence of HLA-A $* 02$ or HLA-CW $* 08$ was associated with a lower proviral burden and decreased prevalence of HAM/TSP (Assone et al. 2016), and the clonality of the infected CD4 T cells is a marker of ATL (Kagdi et al. 2018). However, the association of HLA class 1 with decreased susceptibility for HAM/TSP was not documented in other study (Taghaddosi et al. 2013) and oligoclonal proliferation of HTLV infected cells does not account for the development of myelopathy (Nozuma and Jacobson 2019). Indeed, a recent study suggests that the polymorphism of the IFN- $\gamma+874 \mathrm{~T} / \mathrm{A}$ gene in carriers of the virus may be associated with progression to symptoms and diseases related to HTLV-1 (Queiroz et al. 2018). Although it cannot be ruled out that if the carriers were followed for a longer period, we would observe clinical and neurological diseases or even the development of HAM/TSP; in the present study, we observed neither the appearance of neurological manifestations nor other diseases associated with HTLV-1 in carriers with high PVL, even followed for more than 10 years.

Our data indicate that a large number of HTLV-1 infected subjects with a high PVL and an exaggerated inflammatory response do not develop neurological manifestations, urinary and erectile dysfunction, nor other diseases associated with HTLV-1. These findings suggest that other factors, in addition 
to the PVL and the inflammatory response observed in the peripheral blood, are necessary for carriers to develop HTLV-1-associated diseases.

Acknowledgments We thank Cristiano Franco for the support in the preparation of this manuscript.

Funding information This study was funded by the Conselho Nacional de Pesquisa (CNPq), Ministério de Ciência e Tecnologia, Fundação Maria Emília Freire Pedreira de Carvalho.

\section{Compliance with ethical standards}

The research ethics committee of Federal University of Bahia (UFBA) approved this study. Written consent for the study was obtained from all individuals.

Conflict of interest The authors declare that they have no conflict of interest.

Open Access This article is licensed under a Creative Commons Attribution 4.0 International License, which permits use, sharing, adaptation, distribution and reproduction in any medium or format, as long as you give appropriate credit to the original author(s) and the source, provide a link to the Creative Commons licence, and indicate if changes were made. The images or other third party material in this article are included in the article's Creative Commons licence, unless indicated otherwise in a credit line to the material. If material is not included in the article's Creative Commons licence and your intended use is not permitted by statutory regulation or exceeds the permitted use, you will need to obtain permission directly from the copyright holder. To view a copy of this licence, visit http://creativecommons.org/licenses/by/4.0/.

\section{References}

Ando H, Sato T, Tomaru U, Yoshida M, Utsunomiya A, Yamauchi J, Araya N, Yagishita N, Coler-Reilly A, Shimizu Y, Yudoh K, Hasegawa Y, Nishioka K, Nakajima T, Jacobson S, Yamano Y (2013) Positive feedback loop via astrocytes causes chronic inflammation in virus-associated myelopathy. Brain 136(9):2876-2887. https://doi.org/10.1093/brain/awt183

Araújo AQC, Leite ACC, Lima MASD, Silva MTT (2009) HTLV-1 and neurological conditions: when to suspect and when to order a diagnostic test for HTLV-1 infection? Arq Neuropsiquiatr 67(1):132138. https://doi.org/10.1590/S0004-282X2009000100036

Assone T, Paiva A, Fonseca LAM, Casseb J (2016) Genetic markers of the host in persons living with HTLV-1, HIV and HCV infections. Viruses 8(2). https://doi.org/10.3390/v8020038

Bangham CRM (2018) Human T cell leukemia virus type 1: persistence and pathogenesis. Annu Rev Immunol 36(November 2017):43-71. https://doi.org/10.1146/annurev-immunol-042617-053222

Biswas HH, Engstrom JW, Kaidarova Z, Garratty G, Gibble JW, Newman BH, Smith JW, Ziman A, Fridey JL, Sacher RA, Murphy EL, For the HTLV Outcomes Study (HOST) (2009) Neurologic abnormalities in HTLV-I- and HTLV-II-infected individuals without overt myelopathy. Neurology 73(10):781-789. https:// doi.org/10.1212/WNL.0b013e3181b6bba9

Carvalho EM, Bacellar O, Porto AF, Braga S, Galvão-Castro B, Neva F (2001) Cytokine profile and immunomodulation in asymptomatic human T-lymphotropic virus type 1-infected blood donors. Journal of Acquired Immune Deficiency Syndromes (1999) 27(1):1-6. https://doi.org/10.1097/00126334-200105010-00001

Caskey MF, Morgan DJ, Porto AF, Giozza SP, Muniz AL, Orge GO, Travassos MJ, Barrón Y, Carvalho EM, Glesby MJ (2008) Clinical manifestations associated with HTLV type I infection: a crosssectional study. Aids 23(3):365-371. https://doi.org/10.1089/aid. 2006.0140.Clinical

De Castro-Costa CM, Araújo AQC, Barreto MM, Takayanagui OM, Sohler MP, Silva ELMDA, Paula SMBDE et al (2006) Proposal for diagnostic criteria of tropical spastic Paraparesis/HTLV-I- associated myelopathy (HAM/TSP). AIDS Res Hum Retrovir 22(10): 931-935. https://doi.org/10.1089/aid.2006.22.931

de Oliveira MDFSP, Brites C, Ferraz N, Magalhaes P, Almeida F, Bittencourt AL (2005) Infective dermatitis associated with the human T cell Lymphotropic virus type I in Salvador, Bahia, Brazil. Clin Infect Dis 40(11):e90-e96. https://doi.org/10.1086/430064

de Oliveira CJV, Neto JAC, Andrade RCP, Rocha PN, de Carvalho Filho EM (2017) Risk factors for erectile dysfunction in men with HTLV1. J Sex Med 14(10):1195-1200. https://doi.org/10.1016/j.jsxm. 2017.08.001

Dehée A, Césaire R, Désiré N, Lézin A, Bourdonné O, Béra O, Plumelle Y, Smadja D, Nicolas JC (2002) Quantitation of HTLV-I Proviral load by a TaqMan real-time PCR assay. J Virol Methods 102(1-2): 37-51. https://doi.org/10.1016/S0166-0934(01)00445-1

Demontis MA, Hilburn S, Taylor GP (2013) Human T cell Lymphotropic virus type 1 viral load variability and long-term trends in asymptomatic carriers and in patients with human $\mathrm{T}$ cell lymphotropic virus type 1-related diseases. AIDS Res Hum Retrovir 29(2):359-364. https://doi.org/10.1089/AID.2012.0132

Domingos JA, Soares LS, Bandeira LM, Bonin CM, Vicente ACP, Zanella L, Puga MAM, Tozetti IA, Motta-Castro ARC, da Cunha RV (2017) Cytokine profile and Proviral load among Japanese immigrants and non-Japanese infected with HTLV-1 in a non-endemic area of Brazil. PLoS One 12(4):e0174869. https://doi.org/10.1371/ journal.pone. 0174869

Frenzel L, Moura B, Marcais A, Chapdelaine H, Hermine O (2014) HTLV-1-associated Arthropathy treated with anti-TNF-alpha agent. Joint Bone Spine 81(4):360-361. https://doi.org/10.1016/j.jbspin. 2013.10.006

Futsch N, Mahieux R, Dutartre H (2017) HTLV-1, the other pathogenic yet neglected human retrovirus: from transmission to therapeutic treatment. Viruses 10(1):1-25. https://doi.org/10.3390/v10010001

Garlet GP, Giozza SP, Silveira EM, Claudino M, Santos SB, AvilaCampos MJ, Martins W Jr et al (2010) Association of human T lymphotropic virus 1 amplification of periodontitis severity with altered cytokine expression in response to a standard periodontopathogen infection. Clin Infect Dis 50(3):e11-e18. https://doi.org/10.1086/649871

Gessain A, Mahieux R (2012) Tropical spastic Paraparesis and HTLV-1 associated myelopathy: clinical, epidemiological, virological and therapeutic aspects. Rev Neurol 168(3):257-269. https://doi.org/ 10.1016/j.neurol.2011.12.006

Gessain A, Barin F, Vernant JC, Gout O, Maurs L, Calender A, de Thé G (1985) Antibodies to human T-lymphotropic virus type-I in patients with tropical spastic paraparesis. Lancet (London, England) 2(8452):407-410. https://doi.org/10.1016/S0140-6736(85)92734-5

Gomes JAS, Bahia-Oliveira LMG, Rocha MOC, Martins-Filho OA, Gazzinelli G, Correa-Oliveira R (2003) Evidence that development of severe cardiomyopathy in human Chagas' disease is due to a Th1specific immune response. Infect Immun 71(3):1185-1193. https:// doi.org/10.1128/IAI.71.3.1185-1193.2003

Grassi MFR, Olavarria VN, de Almeida Kruschewsky R, Mascarenhas RE, Dourado I, Correia LCL, de Castro-Costa CM, Galvão-Castro B (2011) Human T cell lymphotropic virus type 1 (HTLV-1) proviral load of HTLV-associated myelopathy/tropical spastic paraparesis (HAM/TSP) patients according to new diagnostic criteria of 
HAM/TSP. J Med Virol 83(7):1269-1274. https://doi.org/10.1002/ jmv. 22087

Guerreiro JB, Santos SB, Morgan DJ, Porto AF, Muniz AL, Ho JL, Teixeira AL, Teixeira MM, Carvalho EM (2006) Levels of serum chemokines discriminate clinical myelopathy associated with human T lymphotropic virus type 1 (HTLV-1)/tropical spastic paraparesis (HAM/TSP) disease from HTLV-1 carrier state. Clin Exp Immunol 145(2):296-301. https://doi.org/10.1111/j.13652249.2006.03150.x

Hansson GK (2005) Inflammation, atherosclerosis, and coronary artery disease. N Engl J Med 352(16):1685-1695. https://doi.org/10.1056/ NEJMra043430

Harris PA, Taylor R, Thielke R, Payne J, Gonzalez N, Conde JG (2009) Research electronic data capture (REDCap) - a metadata driven methodology and workflow process for providing translational research informatict support. J Biomed Inform 42(2):377-381. https:// doi.org/10.1016/j.jbi.2008.08.010.Research

Kagdi H, Demontis MA, Ramos JC, Taylor GP (2018) Switching and loss of cellular cytokine producing capacity characterize in vivo viral infection and malignant transformation in human T-lymphotropic virus type 1 infection. PLoS Pathog 14(2):1-25. https://doi.org/10. 1371/journal.ppat.1006861

Lima CM, Santos S, Dourado A, Carvalho NB, Bittencourt V, Lessa MM, Siqueira I, Carvalho EM (2016) Association of Sicca syndrome with proviral load and proinflammatory cytokines in HTLV-1 infection. J Immunol Res 2016:1-6. https://doi.org/10.1155/2016/8402059

Martin JL, Maldonado JO, Mueller JD, Zhang W, Mansky LM (2016) Molecular studies of HTLV-1 replication: an update. Viruses 8(2):122. https://doi.org/10.3390/v8020031

Martins ML, Guimarães JC, Ribas JG, Romanelli LCF, de Freitas Carneiro-Proietti AB (2017) Long-term follow-up of HTLV-1 proviral load in asymptomatic carriers and in incident cases of HAM/ TSP: what is its relevance as a prognostic marker for neurologic disease? Journal of NeuroVirology 23(1):125-133. https://doi.org/ 10.1007/s13365-016-0484-x

Matsuzaki T, Nakagawa M, Nagai M, Usuku K, Higuchi I, Arimura K, Kubota H, Izumo S, Akiba S, Osame M (2001) HTLV-1 Proviral load correlates with progression of motor disability in HAM/TSP: analysis of $239 \mathrm{HAM}$ /TSP patients including 64 patients followed up for 10 years. Journal of NeuroVirology 7(3):228-234. https://doi. org/10.1080/13550280152403272

Motokawa S, Hasunuma T, Tajima K, Krieg AM, Ito S, Iwasaki K, Nishioka K (1996) High prevalence of arthropathy in HTLV-I carriers on a Japanese Island. Ann Rheum Dis 55(3):193-195 http:// www.ncbi.nlm.nih.gov/pubmed/8712884

Nagai M, Usuku K, Matsumoto W, Kodama D, Takenouchi N, Moritoyo T, Hashiguchi S, Ichinose M, Bangham CRM, Izumo S, Osame M (1998) Analysis of HTLV-I proviral load in 202 HAM/TSP patients and 243 asymptomatic HTLV-I carriers: high proviral load strongly predisposes to HAM/TSP. J Neurovirol 4(6):586-593 https://www. ncbi.nlm.nih.gov/pubmed/10065900

Nakamura S, Nagano I, Yoshioka M, Shimazaki S, Onodera J, Kogure K (1993) Detection of tumor necrosis factor- $\alpha$-positive cells in cerebrospinal fluid of patients with HTLV-I-associated myelopathy. J Neuroimmunol 42(2):127-130. https://doi.org/10.1016/01655728(93)90001-F

Nascimento MCF, Primo J, Bittencourt A, Siqueira I, De Fátima Oliveira M, Meyer R, Schriefer A, Santos SB, Carvalho EM (2009) Infective dermatitis has similar immunological features to human $\mathrm{T}$ lymphotropic virus-type 1-associated myelopathy/tropical spastic Paraparesis. Clin Exp Immunol 156(3):455-462. https://doi.org/10. $1111 /$ j.1365-2249.2008.03869.x

Neco HVP d C, da Silva Teixeira VG, da Trindade ACL, Magalhães PMR, de Lorena VMB, Castellano LRC, de Souza JR, Vasconcelos LR, de Moura PMMF, de Morais CNL (2017) Mediators go together: high production of CXCL9, CXCL10,
IFN- $\gamma$, and TNF- $\alpha$ in HTLV-1-associated myelopathy/tropical spastic paraparesis. AIDS Res Hum Retrovir 33(11):1134-1139. https:// doi.org/10.1089/AID.2016.0296

Nozuma S, Jacobson S (2019) Neuroimmunology of human Tlymphotropic virus type 1-associated myelopathy/tropical spastic paraparesis. Front Microbiol 10(April):885. https://doi.org/10. 3389/fmicb.2019.00885

Olindo S, Lézin A, Cabre P, Merle H, Saint-Vil M, Kaptue ME, Signate A, Césaire R, Smadja D (2005) HTLV-1 proviral load in peripheral blood mononuclear cells quantified in $100 \mathrm{HAM}$ /TSP patients: a marker of disease progression. J Neurol Sci 237(1-2):53-59. https://doi.org/10.1016/j.jns.2005.05.010

Olindo S, Cabre P, Lézin A, Merle H, Saint-Vil M, Signate A, Bonnan M, Chalon A, Magnani L, Cesaire R, Smadja D (2006) Natural history of human T-lymphotropic virus 1-associated myelopathy. Arch Neurol 63:1560-1566. https://doi.org/10.1001/archneur.63.11.1560

Oliveira WN, Ribeiro LE, Schrieffer A, Machado P, Carvalho EM, Bacellar O (2014) The role of inflammatory and anti-inflammatory cytokines in the pathogenesis of human tegumentary leishmaniasis. Cytokine 66(2):127-132. https://doi.org/10.1016/j.cyto.2013.12. 016

Osame M, Usuku K, Izumo S, Ijichi N, Amitani H, Igata A, Matsumoto M, Tara M (1986) HTLV-I associated myelopathy, a new clinical entity. Lancet (London, England) 1(8488):1031-1032. https://doi. org/10.1016/S0140-6736(86)91298-5

Pandya JM, Lundell AC, Andersson K, Nordström I, Theander E, Rudin A (2017) Blood chemokine profile in untreated early rheumatoid arthritis: CXCL10 as a disease activity marker. Arthritis Res Ther 19(1):1-12. https://doi.org/10.1186/s13075-017-1224-1

Poetker SKW, Porto AF, Giozza SP, Muniz AL, Caskey MF, Carvalho EM, Glesby MJ (2011) Clinical manifestations in individuals with recent diagnosis of HTLV type I infection. J Clin Virol 51(1):54-58. https://doi.org/10.1016/j.jcv.2011.02.004

Poiesz BJ, Ruscetti FW, Gazdar AF, Bunn PA, Minna JD, Gallo RC (1980) Detection and isolation of type $C$ retrovirus particles from fresh and cultured lymphocytes of a patient with cutaneous T-cell lymphoma. Proc Natl Acad Sci 77(12):7415-7419. https://doi.org/ 10.1073/pnas.77.12.7415

Poveda C, Fresno M, Gironès N, Martins-Filho OA, Ramírez JD, SantiRocca J, Marin-Neto JA, Morillo CA, Rosas F, Guhl F (2014) Cytokine profiling in Chagas disease: towards understanding the association with infecting Trypanosoma cruzi discrete typing units (A benefit trial sub-study). PLoS One 9(3):1-8. https://doi.org/10. 1371/journal.pone.0091154

Queiroz MAF, Azevedo VN, da Ednelza SGA, Moura TCF, Guimarães Ishak MDO, Ishak R, Vallinoto ACR, Martins Feitosa RN (2018) IFNG $+874 \mathrm{~A} / \mathrm{T}$ polymorphism among asymptomatic HTLV-1infected individuals is potentially related to a worse prognosis. Front Microbiol 9(May):795. https://doi.org/10.3389/fmicb.2018. 00795

Rudin W, Favre N, Bordmann G, Ryffel B (1997) Interferon- $\gamma$ is essential for the development of cerebral malaria. Eur J Immunol 27(4):810 815. https://doi.org/10.1002/eji.1830270403

Santos SB, Porto AF, Muniz AL, de Jesus AR, Magalhães E, Melo A, Dutra WO, Gollob KJ, Carvalho EM (2004) Exacerbated inflammatory cellular immune response characteristics of HAM/TSP is observed in a large proportion of HTLV-I asymptomatic carriers. BMC Infect Dis 4(March):7. https://doi.org/10.1186/1471-2334-4-7

Santos SB, Porto AF, Muniz AL, Luna T, Nascimento MC, Guerreiro JB, Oliveira-Filho J, Morgan DJ, Carvalho EM (2006) Modulation of T cell responses in HTLV-1 carriers and in patients with myelopathy associated with HTLV-1. Neuroimmunomodulation 13(3):145-151. https://doi.org/10.1159/000097259

Santos SB, Oliveira P, Luna T, Souza A, Nascimento M, Siqueira I, Tanajura D, Muniz AL, Glesby MJ, Carvalho EM (2012) Immunological and viral features in patients with overactive bladder 
associated with human T-cell lymphotropic virus type 1 infection. J Med Virol 84(11):1809-1817. https://doi.org/10.1002/jmv.23341

Sato T, Coler-Reilly A, Utsunomiya A, Araya N, Yagishita N, Ando H, Yamauchi J, Inoue E, Ueno T, Hasegawa Y, Nishioka K, Nakajima T, Jacobson S, Izumo S, Yamano Y (2013) CSF CXCL10, CXCL9, and neopterin as candidate prognostic biomarkers for HTLV-1associated myelopathy/tropical spastic Paraparesis. PLoS Negl Trop Dis 7(10):1-11. https://doi.org/10.1371/journal.pntd.0002479

Starling ALB, Martins-Filho OA, Lambertucci JR, Labanca L, de Souza Pereira SR, Teixeira-Carvalho A, Martins ML, Ribas JG, CarneiroProietti ABF, Gonçalves DU (2013) Proviral load and the balance of serum cytocines in HTLV-1-asymptomatic infection and in HTLV1-associated myelopathy/tropical spastic paraparesis (HAM/TSP). Acta Trop 125(1):75-81. https://doi.org/10.1016/j.actatropica. 2012.09.012

Taghaddosi M, Rahim Rezaee SA, Rafatpanah H, Rajaei T, Hosseini RF, Narges V (2013) Association between HLA class I alleles and proviral load in HTLV-I associated myelopathy/tropical spastic paraparesis (HAM/TSP) patients in Iranian population. Iranian Journal of Basic Medical Sciences 16(3):264-267 http://www. ncbi.nIm.nih.gov/pubmed/24470874
Tanajura D, Castro N, Oliveira P, Neto A, Muniz A, Carvalho NB, Orge G, Santos S, Glesby MJ, Carvalho EM (2015) Neurological manifestations in human T-cell lymphotropic virus type 1 (HTLV-1)-infected individuals without HTLV-1-associated myelopathy/tropical spastic paraparesis: a longitudinal cohort study. Clinical Infectious Diseases : An Official Publication of the Infectious Diseases Society of America 61(1):49-56. https://doi.org/10.1093/cid/civ229

Troisgros O, Barnay JL, Darbon-Naghibzadeh F, Olive P, René-Corail P (2017) Retrospective clinic and urodynamic study in the neurogenic bladder dysfunction caused by human $\mathrm{T}$ cell lymphotrophic virus type 1 associated myelopathy/tropical spastic Paraparesis (HAM/ TSP). Neurourol Urodyn 36(2):449-452. https://doi.org/10.1002/ nau. 22952

Uchiyama T, Yodoi J, Sagawa K, Takatsuki K, Uchino H (1977) Adult Tcell leukemia: clinical and hematologic features of 16 cases. Blood 50(3):481-492. https://doi.org/10.1182/blood-2016-06-686618

Publisher's note Springer Nature remains neutral with regard to jurisdictional claims in published maps and institutional affiliations. 